\title{
Podtorze jako regulator w układzie pojazd szynowy-tor
}

\begin{abstract}
$W$ artykule przeprowadzono badania modelu układu pojazd-tor, przyjmujac, że między wektorem wyjścia, którego składowe stanowiq sity działajace w elementach zawieszenia pojazdu, a wektorem wejścia, którego składowe stanowiq przemieszczenia wynikajace z nierówności to$r u$, występuje sprzężenie zwrotne. Zatem $w$ modelu oddziaływań między pojazdem a torem wprowadzono uklad typu regulator.
\end{abstract}

\section{Wprowadzenie}

Pojazd szynowy jest złożonym, dyskretno-ciąłym układem dynamicznym, który podlega podczas ruchu wielowymiarowym stanom obciążenia. Jego stany pracy wynikają w znacznym zakresie z oddziaływań toru.

Tor jest złożonym, dyskretno-ciąłłym układem dynamicznym, który jest poddany wielowymiarowym stanom obciążenia. Jego stany pracy zależą w decydującym stopniu od oddziaływań pojazdu.

Fizyczne i matematyczne modele dynamiki pojazdu szynowego oraz toru prezentowano i analizowano w wielu pracach $[2,4]$. Podstawowe typy modeli toru to modele dyskretne jedno- $\mathrm{i}$ wielowarstwowe oraz modele ciagłe jedno- $\mathrm{i}$ wielowarstwowe. Na podstawie przeprowadzonych eksperymentów opracowano w dziedzinie częstotliwości modele analityczne charakteryzujące pracę toru [2].

W cytowanych opracowaniach przyjęto klasyczną metodę analizy układu badając zależności między wektorem wielkości wejściowych - wymuszeń od toru, a wektorem wielkości wyjściowych - odpowiedzi układu na kierunkach stopni swobody reprezentujących dynamikę pojazdu.

W artykule przyjęto metodę badania modelu układu pojazdtor przyjmując, że między wektorem wyjścia, którego składowe stanowią siły działające w elementach zawieszenia pojazdu, a wektorem wejścia, którego składowe stanowią przemieszczenia wynikające $\mathrm{z}$ nierówności toru oraz podatności podtorza, występuje sprzężenie zwrotne. Zatem w modelu oddziaływań między pojazdem a torem wprowadzono układ typu regulator.

Celem artykułu jest wyznaczenie charakterystyk sztywnościowych i tłumieniowych modelu podtorza, przy założeniu, że w układzie występuje sprzężenie zwrotne.

2. Wyznaczanie parametrów modelu podtorza dla zadanych charakterystyk własnych modelu układu Analizę modelu układu przeprowadzono w zakresie częstotliwości $0 \div 30 \mathrm{~Hz}$. Przyjęto, że uwzględnienie modelu podtorza wpływa w niewielkim stopniu na charakterystyki własne modelu pojazdu.

Do opisu dynamiki układu wykorzystano formalizm transmitancji operatorowej oraz metodę przestrzeni stanu.

Do wyznaczenia parametrów regulatora zastosowano metodę optymalizacji z kwadratowym wskaźnikiem jakości $[1,3]$.

Równania ruchu dyskretnego, liniowego, stacjonarnego modelu układu o $n$ stopniach swobody przedstawiono w postaci:

$$
\mathbf{M} \ddot{\mathbf{q}}+\mathbf{C} \dot{\mathbf{q}}+\mathbf{K q}=\mathbf{G f}
$$

a równanie wyjść jako:

$$
\mathbf{y}=\mathbf{Z q}
$$

gdzie:

$\mathbf{q}, \dot{\mathbf{q}}, \ddot{\mathbf{q}}$ - wektory przemieszczeń, prędkości i przyspieszeń uogólnionych,

f - wektor wymuszeń,

$\mathbf{y}$ - wektor wielkości wyjściowych,

$\mathbf{M}, \mathbf{C}, \mathbf{K}$ - macierze bezwładności, tłumienia i sztywności,

$\mathbf{G}$ - macierz wejść,

$\mathbf{Z}$ - macierz wyjść.

Po przeprowadzeniu transformacji Laplace'a równań (1) oraz (2) i przyjęciu zerowych warunków początkowych $\dot{\mathbf{q}}(0)=\mathbf{q}(0)=\mathbf{0}$, wyznaczono transmitancję operatorową modelu układu $\mathbf{H}(s)$ jako:

$$
\mathbf{H}(s)=\mathbf{Z}\left(\mathbf{K}+\mathbf{C} s+\mathbf{M} s^{2}\right)^{-1} \mathbf{G}
$$

gdzie: $s$ jest zmienną operatorową.

Dokonując podstawienia $s=j \omega$, gdzie $\omega$ jest częstotliwością kołową, a $j$ jest jednostką urojoną, do zależności (3) uzyskano macierz transmitancji widmowej $H(j \omega)$. Do oceny zjawisk zachodzących w układzie wykorzystano charakterystykę amplitudowo-częstotliwościową oraz fazowoczęstotliwościową [3].

W celu zastosowania $\mathrm{w}$ analizie metody przestrzeni stanu wprowadzono $2 n$-wymiarowy wektor stanu $\mathbf{x}$, a równania (1) i (2) przedstawiono w postaci równania stanu:

$$
\dot{\mathbf{x}}=\mathbf{A x}+\mathbf{B u}
$$

gdzie macierz A jest nazywana macierzą stanu, macierz $\mathbf{B}$ macierzą wejść, a u-wektorem wejść.

2.1. Wyznaczanie parametrów modelu podtorza dla zadanych charakterystyk własnych $\mathrm{z}$ wykorzystaniem transmitancji operatorowej

Do badań przyjęto model układu, jak opisano równaniem (1)

$$
m \ddot{q}(t)+c \dot{q}(t)+k q(t)=c \dot{\xi}(t)+k \xi(t)
$$

gdzie:

$m$ - masa nadwozia,

$c$ - stała tłumika w zawieszeniu nadwozia,

$k$ - stała sprężyny w zawieszeniu nadwozia,

$q$ - współrzędna uogólniona,

$\xi$ - funkcja charakteryzująca nierówność toru.

Przyjęto, że wejściem jest nierówność toru $\xi(t)$, a wektor wyjścia stanowią: siła $\mathrm{w}$ sprężynie zawieszenia $\mathrm{F}_{\mathrm{S}}(t)$ oraz siła w tłumiku zawieszenia $\mathrm{F}_{\mathrm{T}}(t)$.

Po przeprowadzeniu transformacji Laplace’a równania (5) uzyskano:

$$
m s^{2} q(s)+c s q(s)+k q(s)=c s \xi(s)+k \xi(s)
$$


Transmitancję operatorową między siłą w sprężynie zawieszenia a nierównością toru zapisano jako:

$$
H_{11}(s)=\frac{k[q(s)-\xi(s)]}{\xi(s)}
$$

Transmitancję operatorową między siłą w tłumiku zawieszenia a nierównością toru zapisano jako:

$$
H_{21}(s)=\frac{c s[q(s)-\xi(s)]}{\xi(s)}
$$

Po przeprowadzeniu odpowiednich przekształceń uzyskano transmitancję $H_{11}(s)$ w postaci:

$$
H_{11}(s)=\frac{-m k s^{2}}{m s^{2}+c s+k}
$$

oraz transmitancję $H_{21}(s)$ w postaci:

$$
H_{21}(s)=\frac{-m c s^{3}}{m s^{2}+c s+k}
$$

Do badań przyjęto, że wyjściem jest siła $\mathrm{F}(t)$ jako suma sił $\mathrm{F}_{\mathrm{S}}(t)$ i $\mathrm{F}_{\mathrm{T}}(t)$. Transmitancję zastępczą układu przyjęto zatem $\mathrm{w}$ postaci:

$$
H_{O}(s)=\frac{-m c s^{3}-m k s^{2}}{m s^{2}+c s+k}
$$

co przedstawiono w zapisie operatorowym na rys. 1.

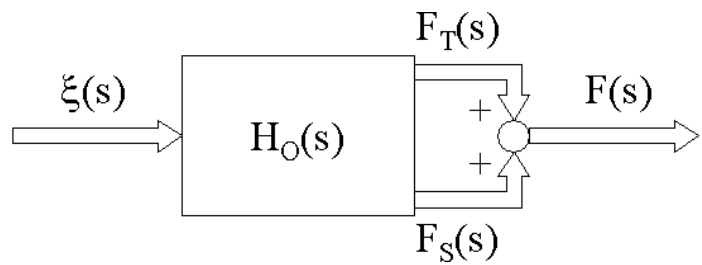

Rys. 1. Schemat struktury badanego układu

Przyjęto, że między wyjściem w postaci siły działającej w zawieszeniu, a wejściem $\mathrm{w}$ postaci przemieszczenia wynikającego $\mathrm{z}$ nierówności toru i podatności podtorza, występuje sprzężenie zwrotne. Transmitancję elementu występującego w pętli sprzężenia zwrotnego określono jako stosunek transformaty wyjścia $\mathrm{w}$ postaci przemieszczenia do transformaty wejścia w postaci siły. Schemat układu z pętlą sprzężenia zwrotnego przy wariantach regulatora w postaci:

- $\quad$ elementu sprężystego o transmitancji:

$$
H_{R}^{k}(s)=\frac{1}{k_{R}}
$$

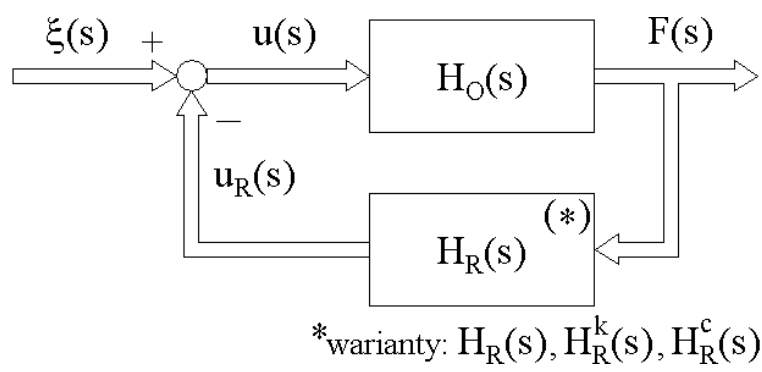

Rys. 2. Schemat struktury układu z założonym sprzężeniem zwrotnym
- $\quad$ elementu tłumieniowego o transmitancji:

$$
H_{R}^{c}(s)=\frac{1}{c_{R} s}
$$

- $\quad$ elementu sprężysto-tłumieniowego o transmitancji:

$$
H_{R}(s)=\frac{1}{k_{R}+c_{R} s}
$$

przedstawiono w zapisie operatorowym na rys. 2 .

Transmitancję zastępczą $H_{z}^{k}(s)$ dla wariantu układu z regulatorem $H_{R}^{k}(s)$ wyznaczono w postaci:

$$
H_{z}^{k}(s)=\frac{-k_{R} m c s^{3}-k_{R} m k s^{2}}{-m c s^{3}+\left(k_{R} m-m k\right) s^{2}+k_{R} c s+k_{R} k}
$$

Transmitancję zastępczą $H_{z}^{c}(s)$ dla wariantu układu z regulatorem $H_{R}^{c}(s)$ wyznaczono w postaci:

$$
H_{z}^{c}(s)=\frac{-m c_{R} c s^{3}-m k c_{R} s^{2}}{\left(c_{R} m-m c\right) s^{2}+\left(c_{R} c-m k\right) s+c_{R} k}
$$

Transmitancję zastępczą $H_{z}(s)$ dla wariantu układu z regulatorem $H_{R}(s)$ wyznaczono w postaci:

$$
H_{z}(s)=\frac{-m c_{R} c s^{4}-\left(m k c_{R}+m k c\right) s^{3}-m k k_{R} s^{2}}{\left(c_{R} m-m c\right) s^{3}+\left(k_{R} m+c_{R} c-m k\right) s^{2}+\left(k_{R} c+c_{R} k\right) s+k k_{R}}
$$

W celu zbadania wpływu zależności między charakterystykami modelu pojazdu a charakterystykami modelu podtorza na charakterystyki własne układu, wprowadzono bezwymiarowy współczynnik $V$ dla charakterystyk sztywnościowych:

$$
V_{i}=\frac{k_{R i}}{k}
$$

oraz bezwymiarowy współczynnik $W$ dla charakterystyk tłumieniowych:

$$
W_{j}=\frac{c_{R j}}{c}
$$

Transmitancję zastępczą (17) po wprowadzeniu współczynnika $V$ zapisano wzorem:

$H_{z}^{V}=\frac{-\frac{m c_{R} c}{k^{2}} s^{4}-\left(\frac{m c_{R}}{k}+\frac{m c}{k} V\right) s^{3}-m V s^{2}}{\left(\frac{c_{R} m}{k^{2}}-\frac{m c}{k^{2}}\right) s^{3}+\left(V \frac{m}{k}+\frac{c_{R} c}{k^{2}}-\frac{m}{k}\right) s^{2}+\left(V \frac{c}{k}+\frac{c_{R}}{k}\right) s+V}$

Transmitancję zastępczą (17) po wprowadzeniu współczynnika $W$ zapisano wzorem:

$$
H_{z}^{W}=\frac{-m W s^{4}-\left(\frac{m k}{c} W+\frac{m k_{R}}{c}\right) s^{3}-\frac{m k k_{R}}{c^{2}} s^{2}}{\left(\frac{m}{c} W-\frac{m}{c}\right) s^{3}+\left(\frac{k_{R} m}{c^{2}}+W-\frac{m k}{c^{2}}\right) s^{2}+\left(\frac{k_{R}}{c}+\frac{k}{c} W\right) s+\frac{k k_{R}}{c^{2}}}
$$

Analizę numeryczną przeprowadzono dla przyjętych danych charakteryzujących model pojazdu: 
$m=2200[\mathrm{~kg}]$

$k=920[\mathrm{kN} / \mathrm{m}]$

$c=27[\mathrm{kN} \cdot \mathrm{s} / \mathrm{m}]$

Wartości własne modelu pojazdu wyznaczono znajdując pierwiastki mianownika transmitancji (11):

$\lambda_{1,2}=-6,1364 \pm j 19,5071$

Pierwiastkom tym odpowiada częstotliwość tłumionych drgań własnych:

$\omega_{d}=20,45[\mathrm{rad} / \mathrm{s}]$

Dla przyjętego modelu przeprowadzono badania w dziedzinie częstotliwości. Wyznaczone charakterystyki amplitudowo-częstotliwościowe odpowiadające transmitancji wyrażonej wzorami (9), (10) i (11) pokazano na rys. 3, a charakterystyki fazowo-częstotliwościowe na rys. 4.

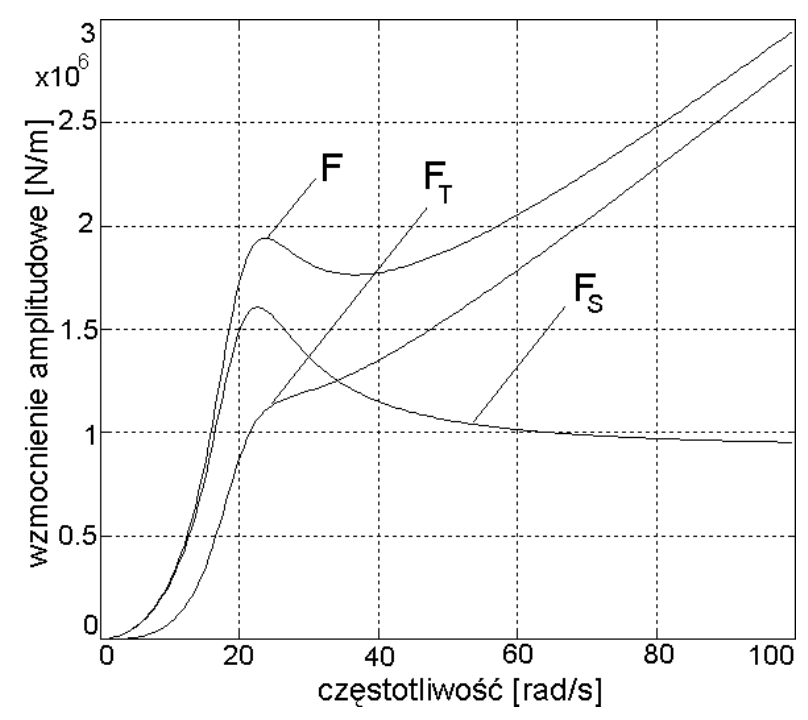

Rys. 3. Charakterystyki amplitudowo-częstotliwościowe dla modelu pojazdu

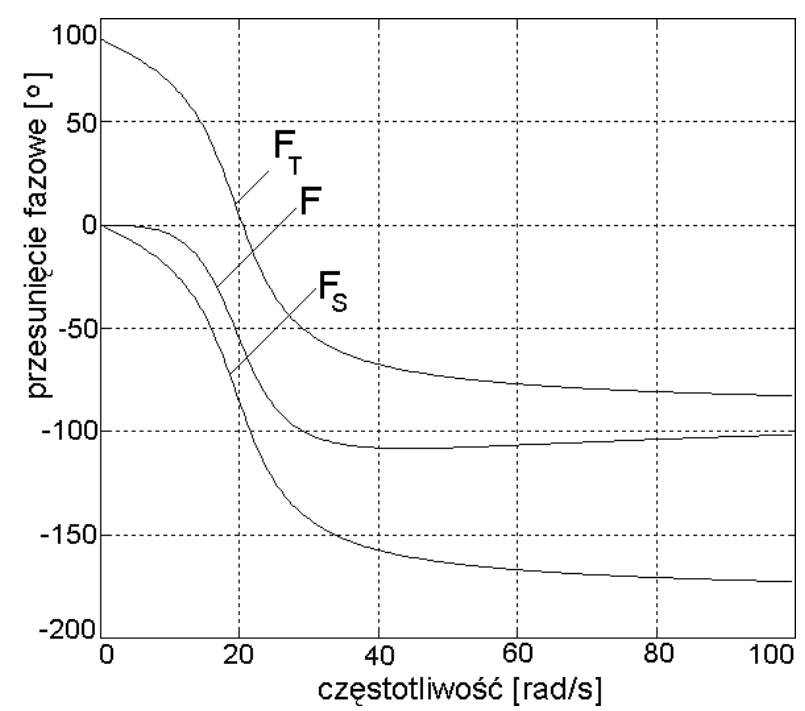

Rys. 4. Charakterystyki fazowo-częstotliwościowe dla modelu pojazdu

Do analizy badanego układu przyjęto następujące wartości stałych $k_{\mathrm{Rs}}$ :
$k_{1}=1,0 \cdot 10^{7}[\mathrm{~N} / \mathrm{m}]$,
$k_{2}=0,5 \cdot 10^{8}[\mathrm{~N} / \mathrm{m}]$,
$k_{3}=1,0 \cdot 10^{8}[\mathrm{~N} / \mathrm{m}]$,
$k_{4}=2,0 \cdot 10^{8}[\mathrm{~N} / \mathrm{m}]$,
oraz wartości stałych $c_{\mathrm{Rq}}$ :

Transmitancja operatorowa $H_{z}^{k}(s)$ modelu (15) świadczy o niestabilności układu (bieguny transmitancji leżą w dodatniej półpłaszczyźnie zespolonej).

Jest to istotne stwierdzenie świadczące o tym, że w modelu podtorza oprócz elementu sprężystego konieczne jest przyjęcie elementu thumieniowego.

Dla przyjętych stałych $c_{\mathrm{R}}$ przeprowadzono analizę częstotliwościową modelu układu (16). Stwierdzono, że przyjęty model regulatora w postaci (13) nie umożliwia uzyskania charakterystyk własnych układu ze sprzężeniem zwrotnym o wartościach bliskich wartościom własnym modelu pojazdu. Zatem nie spełnia on przyjętego założenia, aby wartości własne modelu układu ze sprzężeniem zwrotnym były w przybliżeniu równe wartościom własnym modelu pojazdu. Przykładowe przebiegi charakterystyki amplitudowo-częstotliwościowej dla modelu (16) przedstawiono na rys. 5.

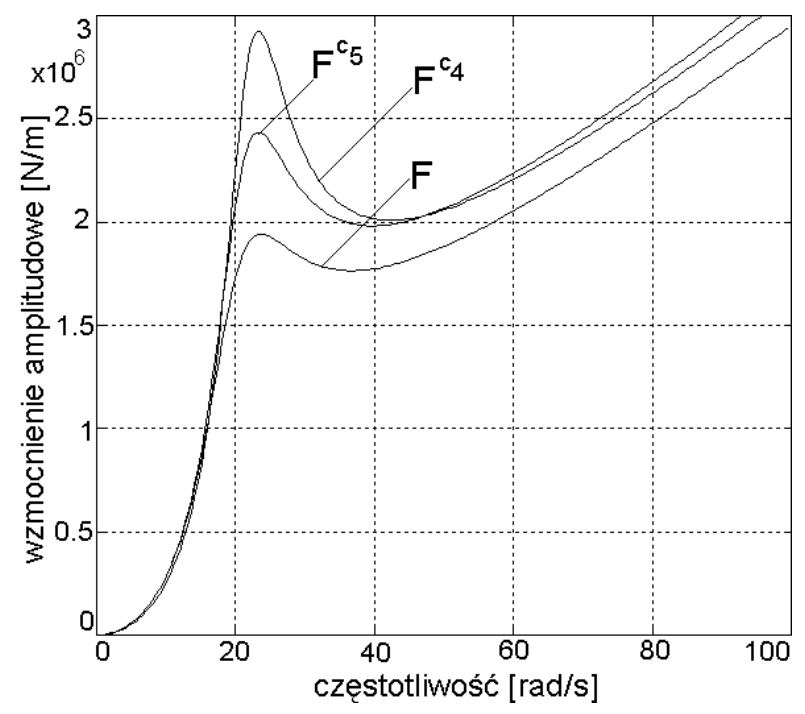

Rys. 5. Charakterystyki amplitudowo-częstotliwościowe dla modelu ze sprzężeniem zwrotnym opisanego transmitancją $H_{z}^{c}(s)$ dla wybranych wariantów

Do dalszych badań przyjęto model podtorza jako układ o charakterystykach sprężystych i tłumieniowych. Badania przeprowadzono dla modelu o transmitancji $H_{z}(s)(17)$.

Dla współczynnika $V_{p}$ przyjęto wartości:

$V_{1}=1$,

$V_{2}=5$,

$V_{3}=10$

$V_{4}=100$,

a dla współczynnika $W_{r}$ przyjęto wartości:

$W_{1}=1$,

$W_{2}=5$,

$W_{3}=10$,

$W_{4}=50$.

Bieguny transmitancji (20) dla wybranych wartości współczynnika $V$ zebrano w tabeli 1 . 
Bieguny transmitancji $H_{z}^{V}(s)$ dla wybranych wartości wspólczynnika $V$

\begin{tabular}{|c|c|c|c|}
\hline \multirow{2}{*}{$\begin{array}{c}\text { Wariant } \\
\mathrm{V}_{\mathrm{p}} \mathrm{c}_{\mathrm{q}}\end{array}$} & \multicolumn{3}{|c|}{ Bieguny transmitancji } \\
\cline { 2 - 4 } & $\lambda_{1}$ & $\lambda_{2}$ & $\lambda_{3}$ \\
\hline $\mathrm{V}_{2} \mathrm{c}_{3}$ & $-68,06$ & $\begin{array}{c}-7,11 \\
+j 20,2\end{array}$ & $\begin{array}{c}-7,11 \\
-j 20,2\end{array}$ \\
\hline $\mathrm{V}_{3} \mathrm{c}_{3}$ & $-368,8$ & $\begin{array}{c}-6,34 \\
+j 19,59\end{array}$ & $\begin{array}{c}-6,34 \\
-j 19,59\end{array}$ \\
\hline $\mathrm{V}_{4} \mathrm{c}_{3}$ & $-742,9$ & $\begin{array}{c}-6,24 \\
+j 19,55\end{array}$ & $\begin{array}{c}-6,24 \\
-j 19,55\end{array}$ \\
\hline $\mathrm{V}_{2} \mathrm{c}_{4}$ & $-48,04$ & $\begin{array}{c}-7,01 \\
+j 20,34\end{array}$ & $\begin{array}{c}-7,01 \\
-j 20,34\end{array}$ \\
\hline $\mathrm{V}_{3} \mathrm{c}_{4}$ & $-262,09$ & $\begin{array}{c}-6,34 \\
+j 19,6\end{array}$ & $\begin{array}{c}-6,34 \\
-j 19,6\end{array}$ \\
\hline $\mathrm{V}_{4} \mathrm{c}_{4}$ & $-528,19$ & $\begin{array}{c}-6,24 \\
+j 19,55\end{array}$ & $\begin{array}{c}-6,24 \\
-j 19,55\end{array}$ \\
\hline
\end{tabular}

Bieguny transmitancji (21) dla wybranych wartości współczynnika $W$ zebrano w tabeli 2.

Bieguny transmitancji $H_{z}^{W}(s)$ dla wy-

branych wartości wspólczynnika $W$

Tabela 2

\begin{tabular}{|c|c|c|c|}
\hline \multirow{2}{*}{$\begin{array}{c}\text { Wariant } \\
\mathrm{W}_{\mathrm{r}} \mathrm{k}_{\mathrm{s}}\end{array}$} & \multicolumn{3}{|c|}{ Bieguny transmitancji } \\
\cline { 2 - 4 } $\mathrm{W}_{2} \mathrm{k}_{2}$ & $-457,14$ & $\begin{array}{c}-6,32 \\
\lambda_{2}\end{array}$ & $\lambda_{3}$ \\
\hline $\mathrm{W}_{3} \mathrm{k}_{2}$ & $-202,97$ & $\begin{array}{c}-6,32 \\
+j 19,5\end{array}$ & $\begin{array}{c}-619,52 \\
-6,32\end{array}$ \\
\hline $\mathrm{W}_{4} \mathrm{k}_{2}$ & $-37,1$ & $\begin{array}{c}-6,26 \\
+j 19,6\end{array}$ & $\begin{array}{c}-6,219,6 \\
-j 19,6\end{array}$ \\
\hline $\mathrm{W}_{2} \mathrm{k}_{3}$ & $-920,29$ & $\begin{array}{c}-6,23 \\
+j 19,54\end{array}$ & $\begin{array}{l}-6,23 \\
-j 19,54\end{array}$ \\
\hline $\mathrm{W}_{3} \mathrm{k}_{3}$ & $-408,91$ & $\begin{array}{c}-6,23 \\
+j 19,55\end{array}$ & $\begin{array}{c}-6,23 \\
-j 19,55\end{array}$ \\
\hline $\mathrm{W}_{4} \mathrm{k}_{3}$ & $-74,97$ & $\begin{array}{c}-6,22 \\
+j 19,57\end{array}$ & $\begin{array}{c}-6,22 \\
-j 19,57\end{array}$ \\
\hline
\end{tabular}

Przebiegi przykładowych charakterystyk amplitudowoczęstotliwościowych dla modelu (20) przedstawiono na rys. 6 oraz rys. 7 .

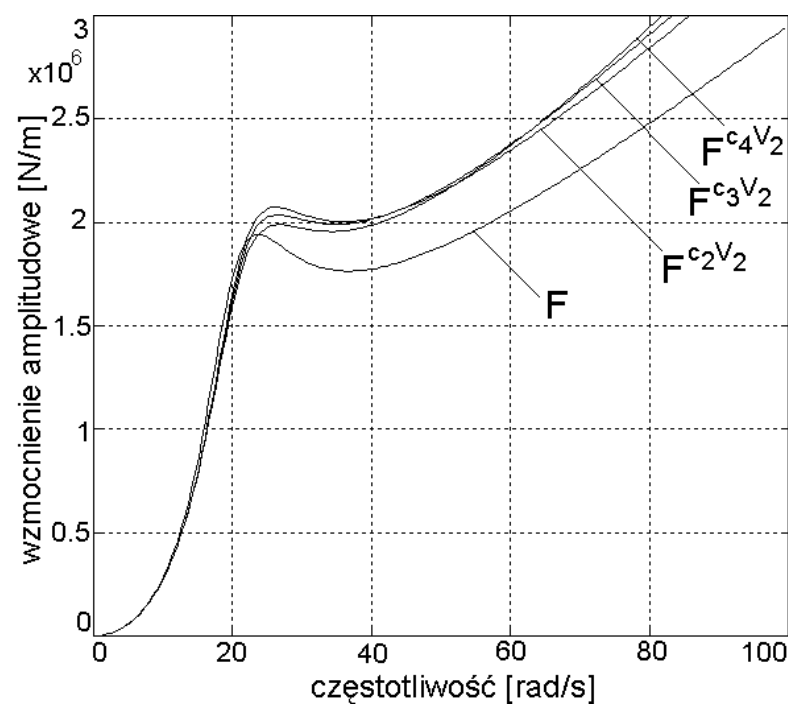

Rys. 6. Charakterystyki amplitudowo-częstotliwościowe dla modelu ze sprzężeniem zwrotnym opisanego transmitancją $H_{z}^{V}(s)$ dla wybranych wariantów

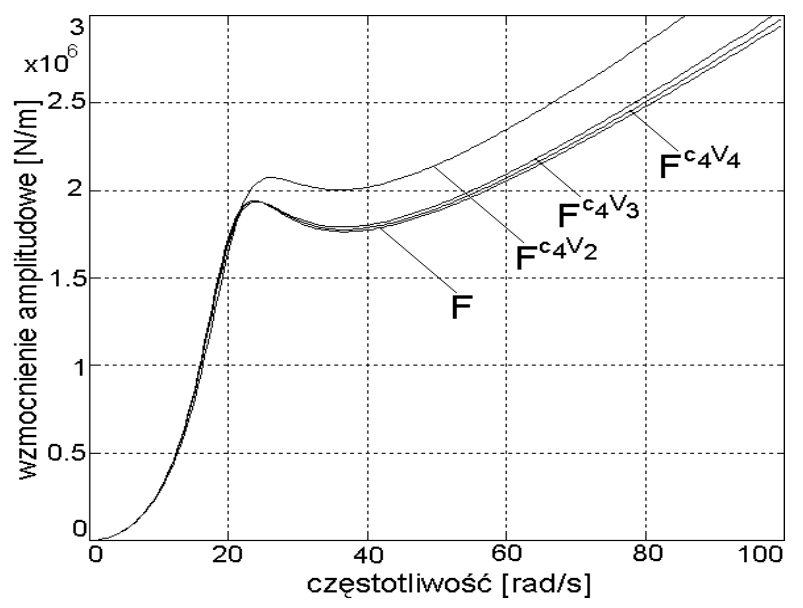

Rys. 7. Charakterystyki amplitudowo-częstotliwościowe dla modelu ze sprzężeniem zwrotnym opisanego transmitancją $H_{z}^{V}(s)$ dla wybranych wariantów

Przebiegi przykładowych charakterystyk amplitudowoczęstotliwościowych dla modelu (21) przedstawiono na rys. 8 oraz rys. 9 .

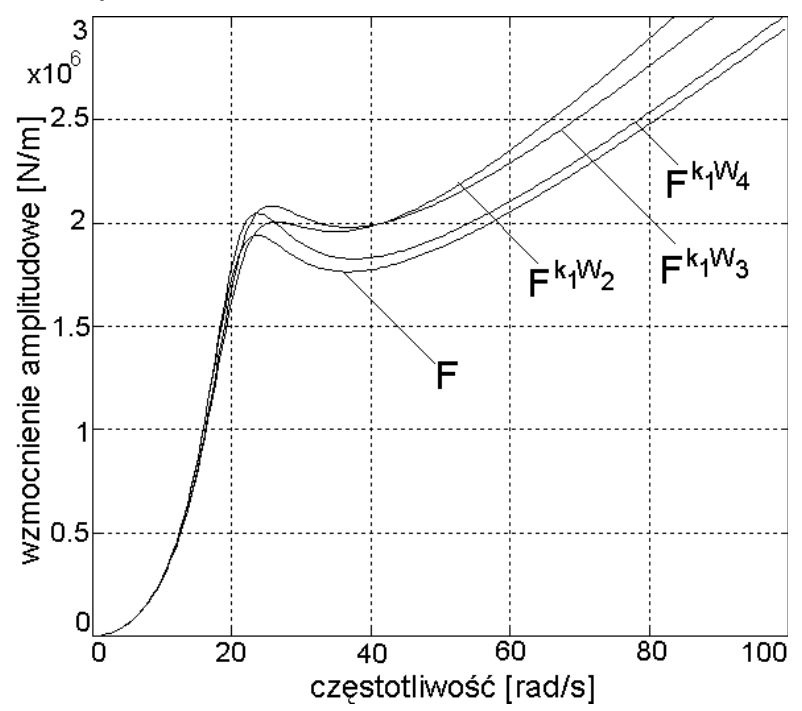

Rys. 8. Charakterystyki amplitudowo-częstotliwościowe dla modelu ze sprzężeniem zwrotnym opisanego transmitancją $H_{z}^{W}(s)$ dla wybranych wariantów

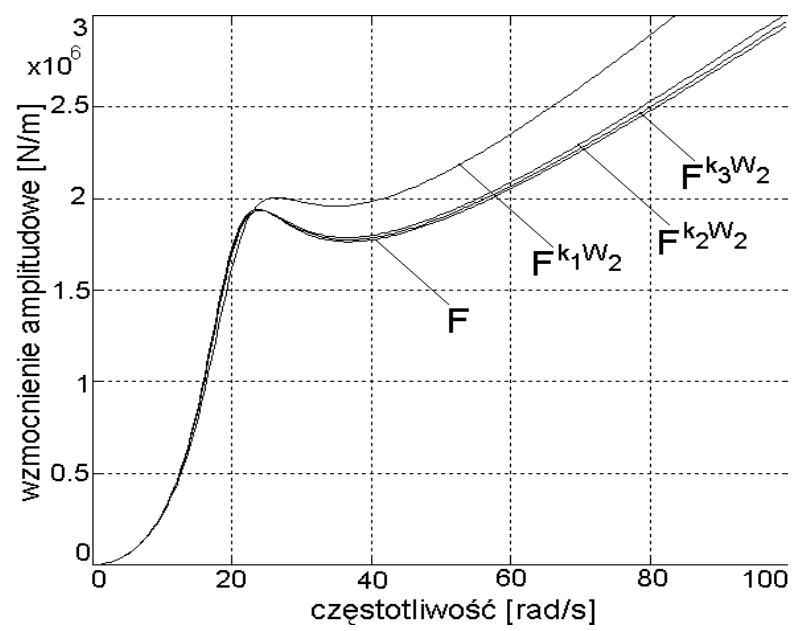

Rys. 9. Charakterystyki amplitudowo-częstotliwościowe dla modelu ze sprzężeniem zwrotnym opisanego transmitancją $H_{z}^{W}(s)$ dla wybranych wariantów 
Na podstawie przeprowadzonej analizy wyznaczonych charakterystyk częstotliwościowych wybrano te wartości współczynników $k_{\mathrm{R}}$ oraz $c_{\mathrm{R}}$ charakteryzujących transmitancję układu ze sprzężeniem zwrotnym $H_{z}(s)(17)$, dla których spełniony jest warunek podobieństwa charakterystyk własnych modelu układu ze sprzężeniem zwrotnym i modelu pojazdu.

Przebiegi przykładowych charakterystyk amplitudowoczęstotliwościowych dla modelu (17) dla wybranych wartości współczynników $k_{\mathrm{R}}$ oraz $c_{\mathrm{R}}$ przedstawiono na rys. 10 oraz rys. 12 , a odpowiadające im charakterystyki fazowoczęstotliwościowe odpowiednio na rys. 11 oraz rys. 13 .

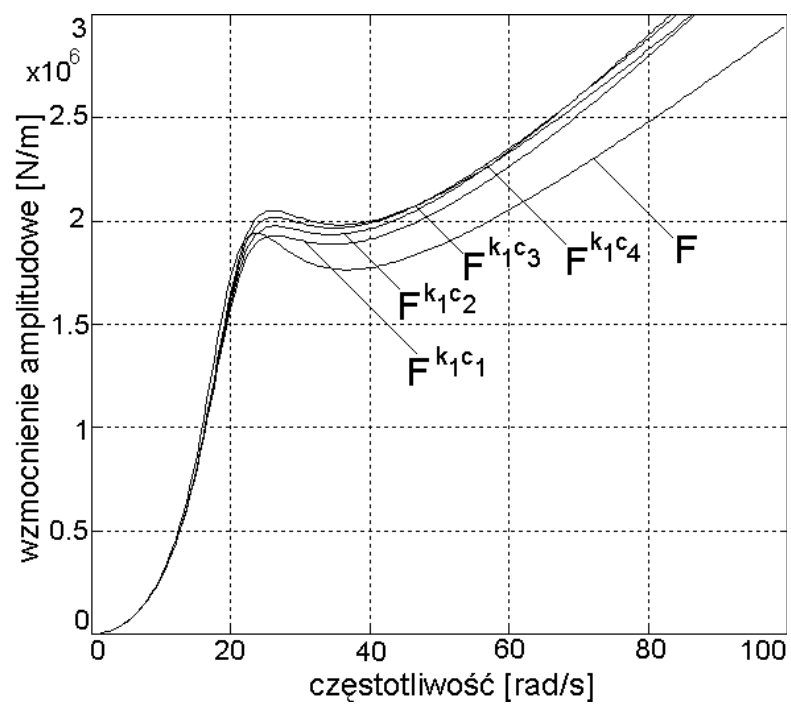

Rys. 10. Charakterystyki amplitudowo-częstotliwościowe dla modelu ze sprzężeniem zwrotnym opisanego transmitancją $H_{z}(s)$ dla wybranych wariantów

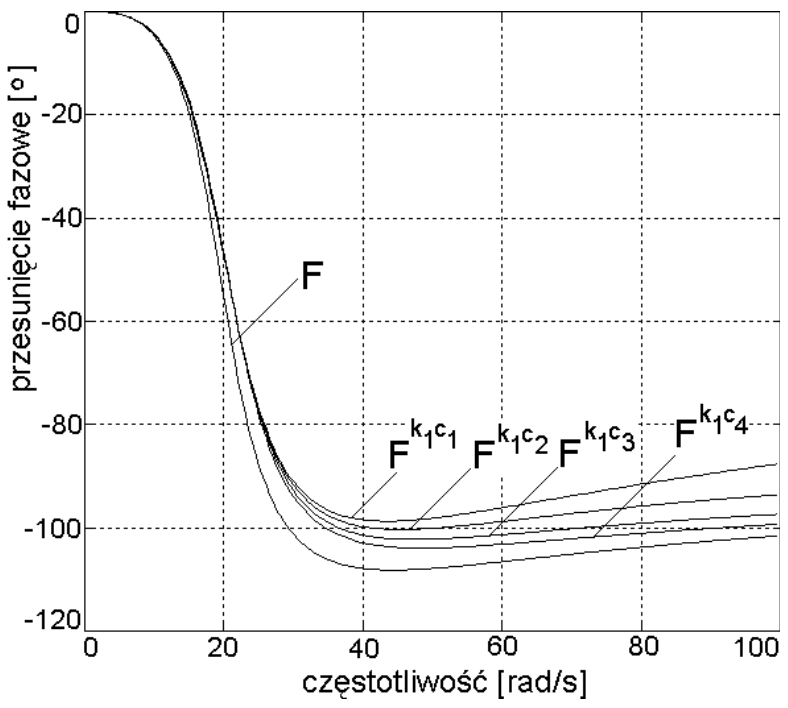

Rys. 11. Charakterystyki fazowo-częstotliwościowe dla modelu ze sprzężeniem zwrotnym opisanego transmitancją $H_{z}(s)$ dla wybranych wariantów

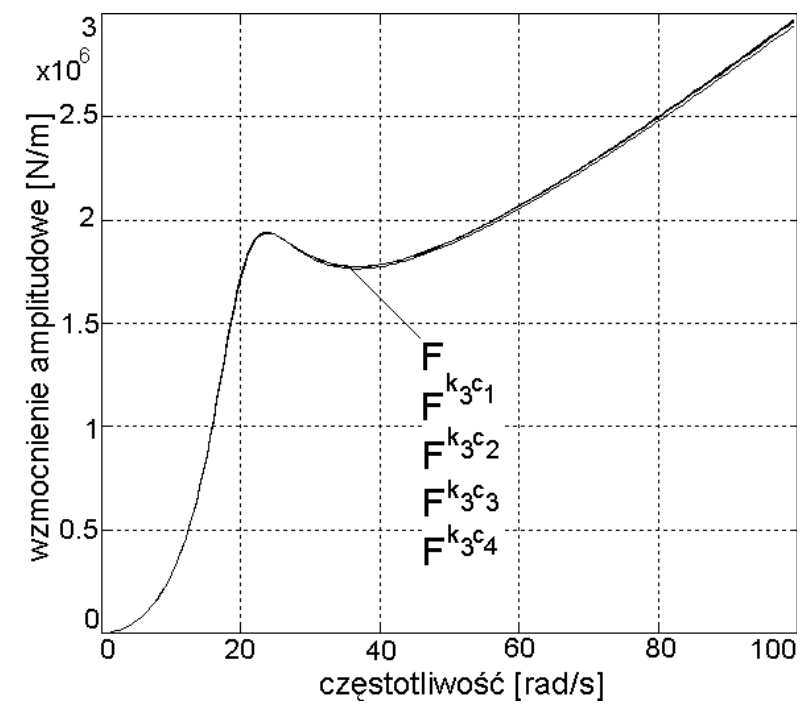

Rys. 12. Charakterystyki amplitudowo-częstotliwościowe dla modelu ze sprzężeniem zwrotnym opisanego transmitancją $H_{z}(s)$ dla wybranych wariantów

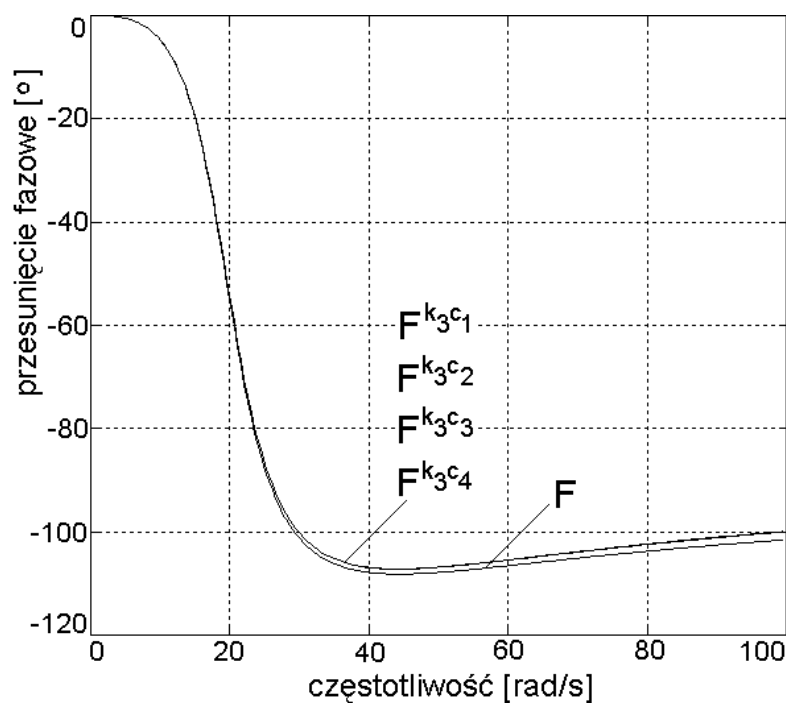

Rys. 13. Charakterystyki fazowo-częstotliwościowe dla modelu ze sprzężeniem zwrotnym opisanego transmitancją $H_{z}(s)$ dla wybranych wariantów

$\mathrm{Na}$ podstawie przeprowadzonej analizy wyników stwierdzono, że spełnienie warunku nie wpływania charakterystyk podtorza na charakterystyki własne modelu pojazdu jest możliwe przy przyjęciu współczynnika $k_{\mathrm{R}}$ równego $1,0 \cdot 10^{8}[\mathrm{~N} / \mathrm{m}]$. Stwierdzono również, że wpływ wartości współczynnika $c_{\mathrm{R}}$ jest niewielki, jeśli współczynnik $k_{\mathrm{R}}$ przyjmuje odpowiednio duże wartości.

\subsection{Wyznaczanie parametrów modelu podtorza dla za- danych charakterystyk wlasnych $z$ zastosowaniem metody przestrzeni stanu}

Do badań przyjęto model układu jak opisano równaniem (4).

Przyjęto wektor stanu $\mathbf{x}$, którego składowymi są siła $\mathrm{w}$ sprężynie $\mathrm{x}_{1}$ :

$$
x_{1}(t)=k(q(t)-\xi(t))
$$

oraz siła w tłumiku $\mathrm{x}_{2}$ :

$$
x_{2}(t)=c(\dot{q}(t)-\dot{\xi}(t))
$$


Odpowiednie pochodne uzyskane po przekształceniach przedstawiono zależnościami:

$$
\begin{gathered}
\dot{x}_{1}(t)=\frac{k}{c} x_{2}(t) \\
\dot{x}_{2}(t)=-\frac{c}{m} x_{1}(t)-\frac{c}{m} x_{2}(t)-c \ddot{\xi}
\end{gathered}
$$

Macierz stanu A ma zatem postać:

$$
\mathbf{A}=\left[\begin{array}{cc}
0 & \frac{k}{c} \\
-\frac{c}{m} & -\frac{c}{m}
\end{array}\right]
$$

a macierz wejść $\mathbf{B}$ :

$$
\mathbf{B}=\left[\begin{array}{c}
0 \\
-c
\end{array}\right]
$$

Związek między wektorem wyjścia a wektorem stanu zapisano w postaci:

$$
\mathbf{y}=\mathbf{D x}
$$

gdzie macierz $\mathbf{D}$ jest macierzą diagonalną $\mathbf{D}=\left[\begin{array}{ll}1 & 0 \\ 0 & 1\end{array}\right]$.

Przyjęto, że podtorze pełni funkcję regulatora $\mathbf{K}_{R}$ w układzie ze sprzężeniem zwrotnym, przy czym wyjście z regulatora $\mathrm{u}_{\mathrm{R}}(t)$ zależy liniowo od wektora stanu $\mathbf{x}(t)$.

$$
u_{R}(t)=-\mathbf{K}_{R} \mathbf{x}(t)
$$

Schemat struktury układu opisanego równaniami od (22) do (29) przedstawiono na rys. 14.

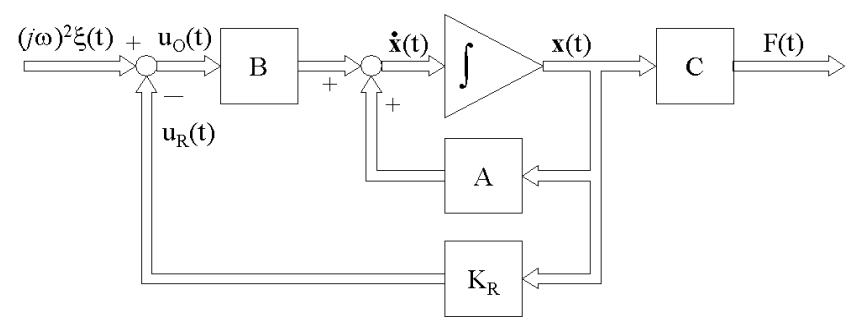

Rys. 14. Schemat struktury układu z regulatorem proporcjonalnym jako modelem podtorza w pętli sprzężenia zwrotnego

Do wyznaczenia wartości $\mathbf{K}_{\mathrm{R}}$ zastosowano metodę optymalizacji z kwadratowym wskaźnikiem jakości [1,3] w postaci:

$$
J=\int_{0}^{\infty}\left(\mathbf{x}^{T} \mathbf{Q} \mathbf{x}+u_{R} L u_{R}\right) d t
$$

gdzie $\mathbf{Q}$ jest rzeczywistą macierzą symetryczną, a $L$ jest wielkością rzeczywistą.

W wyniku podstawienia (29) do wzoru (4) uzyskano:

$$
\dot{\mathbf{x}}=\left(\mathbf{A}-\mathbf{B K}_{R}\right) \mathbf{x}
$$

Po podstawieniu równania (29) do (30) otrzymano zależność:

$$
J=\int_{0}^{\infty} \mathbf{x}\left(\mathbf{Q}+\mathbf{K}_{R}^{T} L \mathbf{K}_{R}\right) \mathbf{x} d t
$$

Równanie opisujące wyjścia z regulatora uzyskane metodą optymalizacji z zastosowaniem wskaźnika kwadratowego przyjmie postać:

$$
u_{R}(t)=-L^{-1} \mathbf{B}^{T} \mathbf{P} \mathbf{x}(t)
$$

gdzie macierz $\mathbf{P}$ jest rozwiązaniem zredukowanego równania Riccati'ego

$$
\mathbf{A}^{T} \mathbf{P}+\mathbf{P A}-\mathbf{P B} L^{-1} \mathbf{B}^{T} \mathbf{P}+\mathbf{Q}=\mathbf{0}
$$

Po przeprowadzeniu wstępnych analiz, do obliczeń przyjęto macierze $\mathbf{Q}_{\mathrm{v}}$ w postaci macierzy diagonalnych $\mathrm{o}$ wartościach na przekątnej równych:

$\mathbf{Q}_{1}=\operatorname{diag}\left[1,0 \cdot 10^{-6}\right], \quad$ oraz wartości współczynnika $L_{\mathrm{w}}$ :

$\mathbf{Q}_{2}=\operatorname{diag}\left[1,0 \cdot 10^{-7}\right], \quad L_{1}=1$,

$\mathbf{Q}_{3}=\operatorname{diag}\left[1,0 \cdot 10^{-8}\right], \quad L_{2}=10$,

$\mathbf{Q}_{4}=\operatorname{diag}\left[1,0 \cdot 10^{-9}\right], \quad L_{3}=100$,

$\mathbf{Q}_{5}=\operatorname{diag}\left[1,0 \cdot 10^{-10}\right], \quad L_{4}=200$.

Dla przyjętych wartości Q i $L$ wyznaczono [5] wartości stałych regulatora $\mathbf{K}_{\mathrm{R}}$ oraz wartości własne układu ze sprzężeniem zwrotnym.

Wartości stałych regulatora $\mathbf{K}_{\mathrm{R}}$ dla wybranych wariantów wartości $\mathbf{Q}_{\mathrm{v}}$ i $L_{\mathrm{w}}$ zebrano w tabeli 3 .

Wartości stałych regulatora $K_{R}$

Tabela 3

\begin{tabular}{|c|c|c|}
\hline \multirow{2}{*}{$\begin{array}{c}\text { Wariant } \\
\mathrm{Q}_{\mathrm{v}} \mathrm{L}_{\mathrm{w}}\end{array}$} & \multicolumn{2}{|c|}{ Stałe regulatora } \\
\cline { 2 - 3 } $\mathrm{k}_{\mathrm{vw} 1}$ & $\mathrm{k}_{\mathrm{vw} 2}$ \\
\hline $\mathrm{Q}_{2} \mathrm{~L}_{1}$ & $-0,992 \mathrm{e}-4$ & $-0,291 \mathrm{e}-3$ \\
\hline $\mathrm{Q}_{2} \mathrm{~L}_{4}$ & $-0,550 \mathrm{e}-6$ & $-0,207 \mathrm{e}-5$ \\
\hline $\mathrm{Q}_{3} \mathrm{~L}_{3}$ & $-0,110 \mathrm{e}-6$ & $-0,415 \mathrm{e}-6$ \\
\hline $\mathrm{Q}_{3} \mathrm{~L}_{4}$ & $-0,550 \mathrm{e}-7$ & $-0,207 \mathrm{e}-6$ \\
\hline $\mathrm{Q}_{4} \mathrm{~L}_{2}$ & $-0,110 \mathrm{e}-6$ & $-0,415 \mathrm{e}-6$ \\
\hline $\mathrm{Q}_{4} \mathrm{~L}_{3}$ & $-0,110 \mathrm{e}-7$ & $-0,415 \mathrm{e}-7$ \\
\hline $\mathrm{Q}_{5} \mathrm{~L}_{1}$ & $-0,110 \mathrm{e}-6$ & $-0,415 \mathrm{e}-6$ \\
\hline $\mathrm{Q}_{5} \mathrm{~L}_{2}$ & $-0,110 \mathrm{e}-7$ & $-0,415 \mathrm{e}-7$ \\
\hline
\end{tabular}

Wartości własne układu $\mathrm{z}$ regulatorem $\mathrm{w}$ pętli sprzężenia zwrotnego

Tabela 4

\begin{tabular}{|c|c|c|}
\hline \multirow{2}{*}{$\begin{array}{c}\text { Wariant } \\
\mathrm{Q}_{\mathrm{v}} \mathrm{L}_{\mathrm{w}}\end{array}$} & \multicolumn{2}{|c|}{ Bieguny transmitancji } \\
\cline { 2 - 3 } $\mathrm{Q}_{2} \mathrm{~L}_{1}$ & $-10,075$ & $\lambda_{2}$ \\
& $+j 20,197$ & $-10,075$ \\
\multirow{2}{*}{$\mathrm{Q}_{2} \mathrm{~L}_{4}$} & $-6,164$ & $-j 20,197$ \\
& $+j 19,507$ & $-6,164$ \\
\hline \multirow{2}{*}{$\mathrm{Q}_{3} \mathrm{~L}_{3}$} & $-6,142$ & $-j 19,507$ \\
\hline \multirow{2}{*}{$\mathrm{Q}_{3} \mathrm{~L}_{4}$} & $+j 19,507$ & $-6,142$ \\
& $-6,139$ & $-j 19,507$ \\
\hline \multirow{2}{*}{$\mathrm{Q}_{4} \mathrm{~L}_{2}$} & $+j 19,507$ & $-6,139$ \\
& $-6,142$ & $-j 19,507$ \\
\hline \multirow{2}{*}{$\mathrm{Q}_{4} \mathrm{~L}_{3}$} & $-6,19,508$ & $-6,142$ \\
& $+j 19,507$ & $-j 19,508$ \\
\hline \multirow{2}{*}{$\mathrm{Q}_{5} \mathrm{~L}_{1}$} & $-6,142$ & $-6,137$ \\
\hline \multirow{2}{*}{$\mathrm{Q}_{5} \mathrm{~L}_{2}$} & $+j 19,508$ & $-j 19,507$ \\
\hline
\end{tabular}


Wartości własne układu $\mathrm{z}$ regulatorem $\mathbf{K}_{\mathrm{R}} \mathrm{W}$ pętli sprzężenia zwrotnego dla wybranych wariantów $\mathbf{Q}_{v}$ i $L_{w}$ zebrano w tabeli 4.

Odpowiednim współczynnikom regulatora $\mathbf{K}_{\mathrm{R}}$ (tabela 3) przypisano fizyczną interpretację jako: współczynnik sztywności podtorza $k_{\mathrm{R}}$ i współczynnik thumienia podtorza $c_{\mathrm{R}}$. Wartości współczynników $k_{\mathrm{R}}$ i $c_{\mathrm{R}}$ zebrano w tabeli 5 .

Współczynniki sztywności i tlumienia pod-
torza odpowiadające współczynnikom re-

\begin{tabular}{|c|c|c|}
\multicolumn{3}{c}{} \\
Wariant \\
$\mathrm{Q}_{\mathrm{v}} \mathrm{L}_{\mathrm{w}}$ & $\mathrm{k}_{\mathrm{R}}[\mathrm{N} / \mathrm{m}]$ & $\mathrm{c}_{\mathrm{R}}[\mathrm{N} \cdot \mathrm{s} / \mathrm{m}]$ \\
\hline $\mathrm{Q}_{2} \mathrm{~L}_{1}$ & $1,008 \mathrm{e} 4$ & $0,342 \mathrm{e} 4$ \\
\hline $\mathrm{Q}_{2} \mathrm{~L}_{4}$ & $1,819 \mathrm{e} 6$ & $0,482 \mathrm{e} 6$ \\
\hline $\mathrm{Q}_{3} \mathrm{~L}_{3}$ & $9,092 \mathrm{e} 6$ & $2,408 \mathrm{e} 6$ \\
\hline $\mathrm{Q}_{3} \mathrm{~L}_{4}$ & $1,818 \mathrm{e} 7$ & $0,481 \mathrm{e} 7$ \\
\hline $\mathrm{Q}_{4} \mathrm{~L}_{2}$ & $9,092 \mathrm{e} 6$ & $2,408 \mathrm{e} 6$ \\
\hline $\mathrm{Q}_{4} \mathrm{~L}_{3}$ & $9,091 \mathrm{e} 7$ & $2,407 \mathrm{e} 7$ \\
\hline $\mathrm{Q}_{5} \mathrm{~L}_{1}$ & $9,092 \mathrm{e} 6$ & $2,408 \mathrm{e} 6$ \\
\hline $\mathrm{Q}_{5} \mathrm{~L}_{2}$ & $9,091 \mathrm{e} 7$ & $2,407 \mathrm{e} 7$ \\
\hline
\end{tabular}

Dla wybranych wariantów macierzy $\mathbf{Q}$ oraz współczynnika $L$ przeprowadzono badania symulacyjne [5], przyjmując wymuszenie $\mathrm{w}$ postaci nierówności toru o charakterze sinusoidalnym:

$$
\xi(t)=0,005 \sin (\omega t)
$$

Do badań przyjęto wymuszenia o częstotliwości $\omega_{1}=10$ $[\mathrm{rad} / \mathrm{s}], \omega_{2}=20[\mathrm{rad} / \mathrm{s}], \omega_{3}=50[\mathrm{rad} / \mathrm{s}], \omega_{4}=100[\mathrm{rad} / \mathrm{s}]$. Przebiegi siły $\mathrm{w}$ sprężynie zawieszenia $\mathrm{F}_{\mathrm{S}}(t)$ i siły $\mathrm{w}$ tłumiku zawieszenia $\mathrm{F}_{\mathrm{T}}(t)$ dla wybranych wariantów $\mathbf{Q}$ i $L$ przy wymuszeniu o częstotliwości $10 \mathrm{rad} / \mathrm{s}$ przedstawiono na rys. 15, o częstotliwości $20 \mathrm{rad} / \mathrm{s}$ na rys. 16, o częstotliwości $50 \mathrm{rad} / \mathrm{s}$ na rys. 17 , a o częstotliwości $100 \mathrm{rad} / \mathrm{s}$ na rys. 18 .

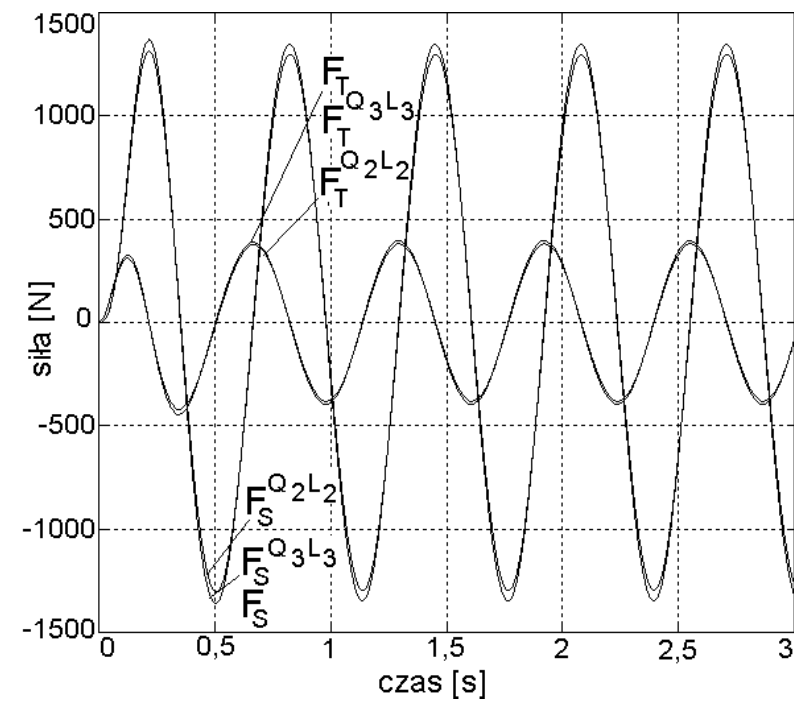

Rys. 15. Przebiegi sił w sprężynie zawieszenia $\left(\mathrm{F}_{\mathrm{S}}\right)$ oraz sił $\mathrm{w}$ tłumiku zawieszenia $\left(\mathrm{F}_{\mathrm{T}}\right)$ dla wymuszenia o częstotliwości $10 \mathrm{rad} / \mathrm{s}$ dla wybranych wariantów

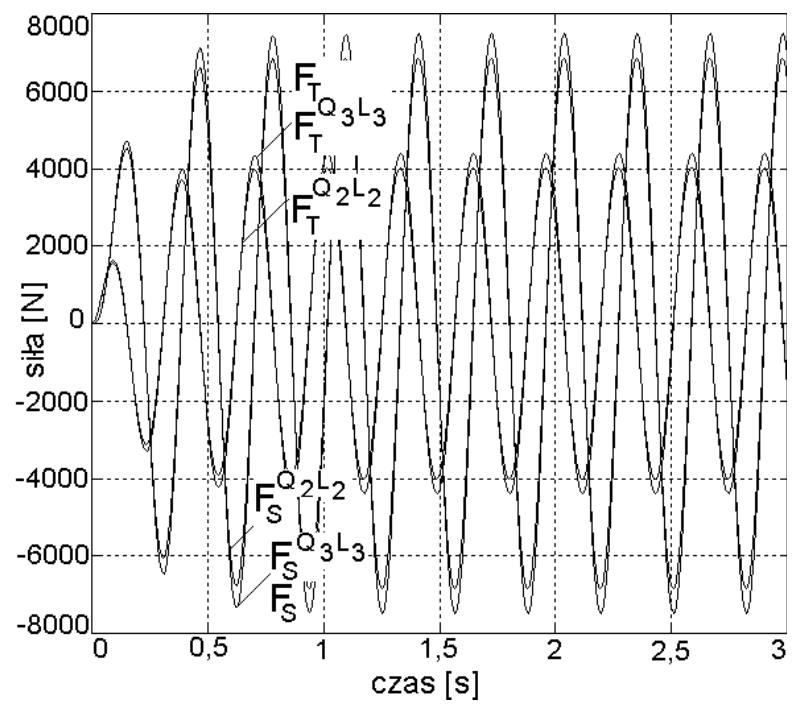

Rys. 16. Przebiegi sił w sprężynie zawieszenia $\left(\mathrm{F}_{\mathrm{S}}\right)$ oraz sił $\mathrm{w}$ tłumiku zawieszenia $\left(\mathrm{F}_{\mathrm{T}}\right)$ dla wymuszenia o częstotliwości $20 \mathrm{rad} / \mathrm{s}$ dla wybranych wariantów

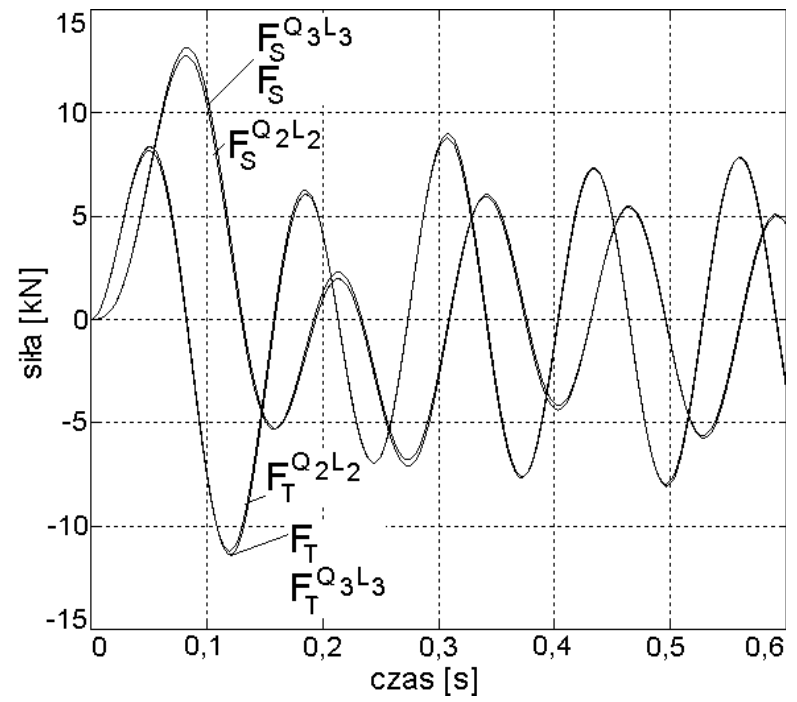

Rys. 17. Przebiegi sił w sprężynie zawieszenia $\left(\mathrm{F}_{\mathrm{S}}\right)$ oraz sił $\mathrm{w}$ tłumiku zawieszenia $\left(\mathrm{F}_{\mathrm{T}}\right)$ dla wymuszenia o częstotliwości 50 $\mathrm{rad} / \mathrm{s}$ dla wybranych wariantów

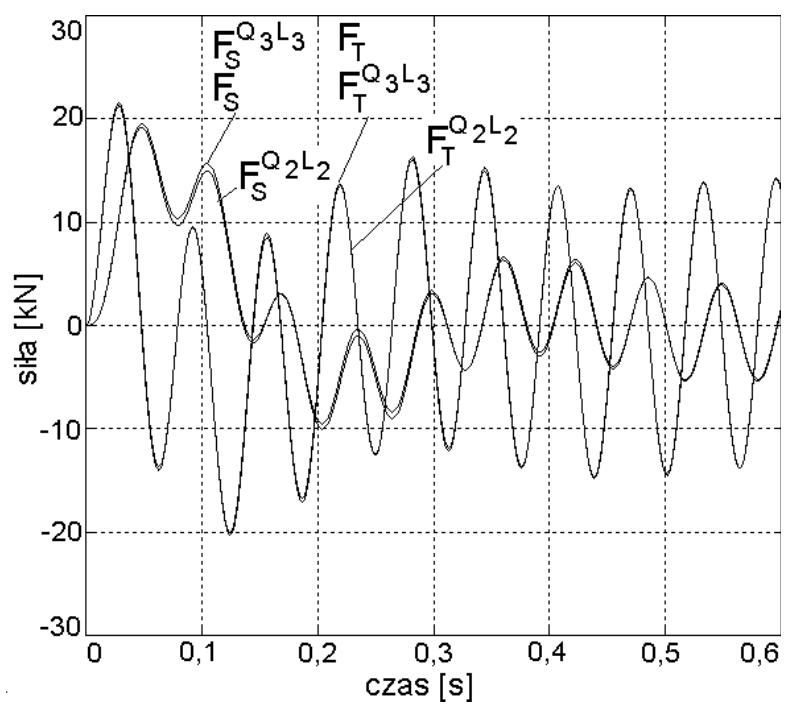

Rys. 18. Przebiegi sił w sprężynie zawieszenia $\left(\mathrm{F}_{\mathrm{S}}\right)$ oraz sił w tłumiku zawieszenia $\left(\mathrm{F}_{\mathrm{T}}\right)$ dla wymuszenia o częstotliwości 100 $\mathrm{rad} / \mathrm{s}$ dla wybranych wariantów 


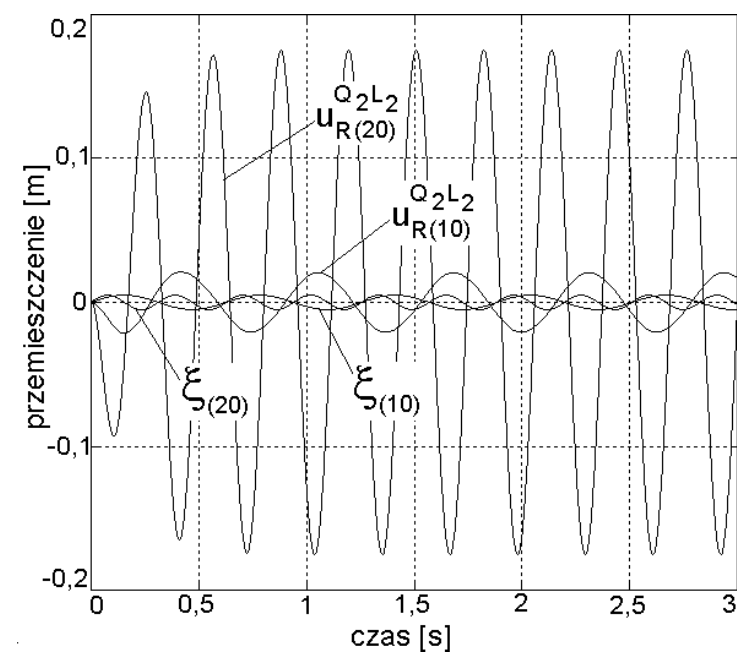

Rys. 19. Przebiegi wymuszenia $\xi(t)$ oraz przemieszczeń $u_{\mathrm{R}}(t)$ przy wymuszeniu o częstotliwości $10 \mathrm{rad} / \mathrm{s}$ oraz $20 \mathrm{rad} / \mathrm{s}$ dla wybranych wariantów

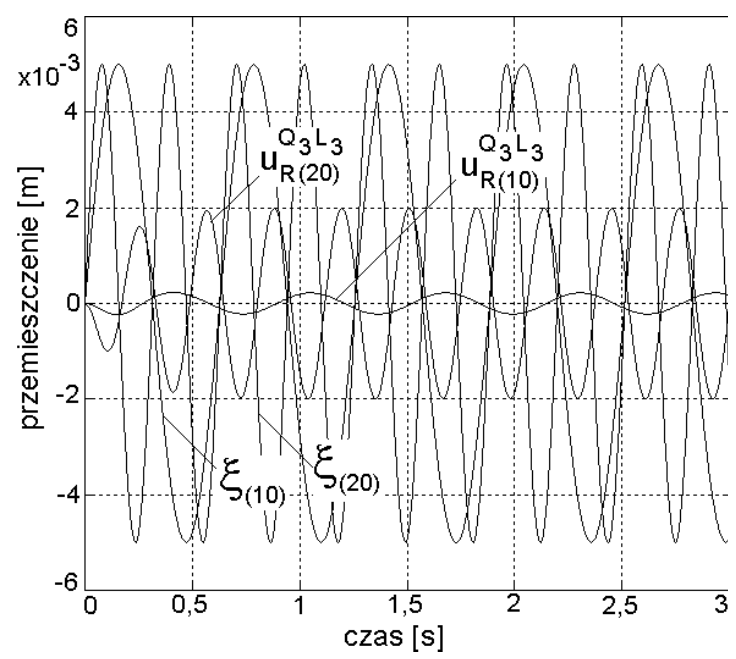

Rys. 20. Przebiegi wymuszenia $\xi(t)$ oraz przemieszczeń $u_{\mathrm{R}}(t)$ przy wymuszeniu o częstotliwości $10 \mathrm{rad} / \mathrm{s}$ oraz $20 \mathrm{rad} / \mathrm{s}$ dla wybranych wariantów

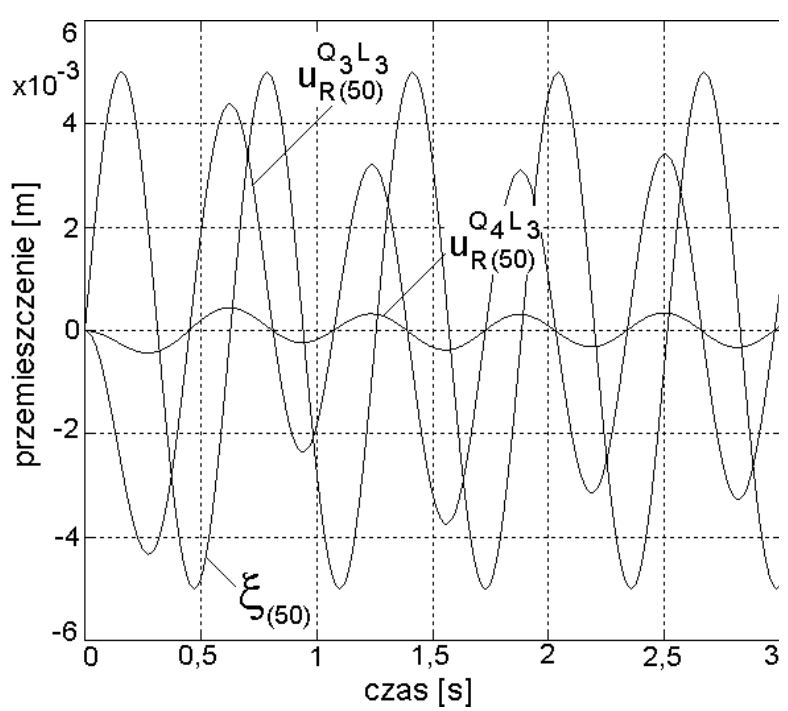

Rys. 21. Przebiegi wymuszenia $\xi(t)$ oraz przemieszczeń $u_{\mathrm{R}}(t)$ przy wymuszeniu o częstotliwości $50 \mathrm{rad} / \mathrm{s}$ dla wybranych wariantów
Przebiegi wymuszenia $\xi(t)$ oraz przemieszczeń $u_{R}(t)$, stanowiących wyjście $\mathrm{z}$ regulatora, dla wybranych wariantów $\mathbf{Q}$ i $L$ przy wymuszeniu o częstotliwości $10 \mathrm{rad} / \mathrm{s}$ oraz $20 \mathrm{rad} / \mathrm{s}$ przedstawiono na rys. 19 i rys. 20, o częstotliwości $50 \mathrm{rad} / \mathrm{s}$ na rys. 21, a o częstotliwości 100 $\mathrm{rad} / \mathrm{s}$ na rys. 22.

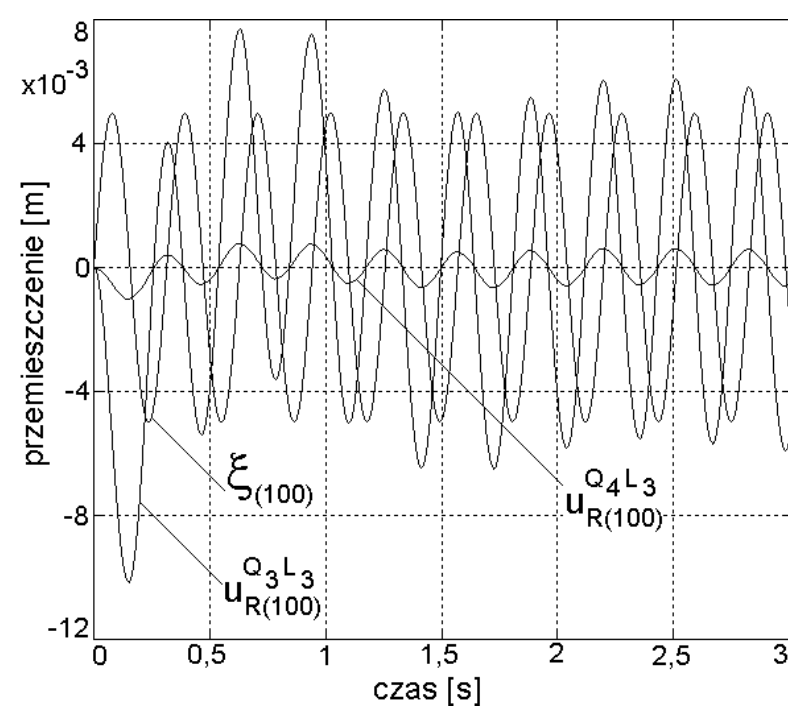

Rys. 22. Przebiegi wymuszenia $\xi(t)$ oraz przemieszczeń $\mathrm{u}_{\mathrm{R}}(t)$ przy wymuszeniu o częstotliwości $100 \mathrm{rad} / \mathrm{s}$ dla wybranych wariantów

Przebiegi wyjścia $\mathrm{z}$ regulatora $\mathrm{u}_{\mathrm{R}}(t)$, przy wymuszeniu o częstotliwościach $10 \mathrm{rad} / \mathrm{s}$ oraz $20 \mathrm{rad} / \mathrm{s}$, uzyskane dla wybranych wartości macierzy $\mathbf{Q}$ i współczynnika $L$ przedstawiono na rys. 23 .

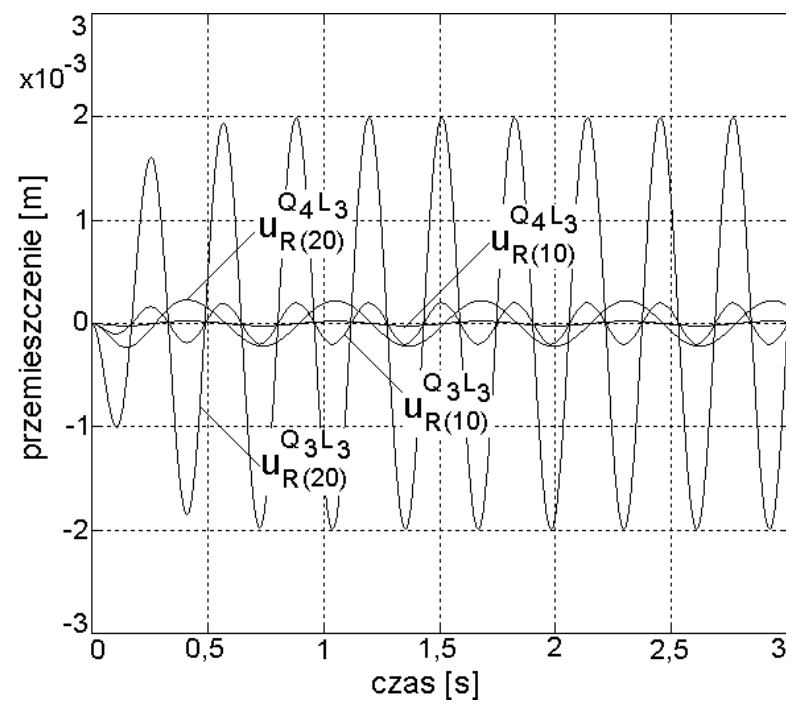

Rys. 23. Przebiegi przemieszczenia $u_{\mathrm{R}}(t)$ przy wymuszeniu o częstotliwościach $10 \mathrm{rad} / \mathrm{s}$ oraz $20 \mathrm{rad} / \mathrm{s}$ dla wybranych wariantów

Wyznaczone wartości współczynników regulatora determinują zmianę funkcji wymuszającej badany układ. Przebiegi wejścia $\mathrm{u}_{\mathrm{o}}(t)$ do układu (rys. 14), jako wynik sumowania przemieszczenia wynikającego z nierówności toru $\xi(t)$ oraz przemieszczenia $\mathrm{u}_{\mathrm{R}}(t)$ wywołanego działaniem sił w zawieszeniu pojazdu $\mathrm{F}(t)$ działających $\mathrm{w}$ układzie ze sprzężeniem zwrotnym, dla wybranych wariantów wymuszeń o częstotliwości $10 \mathrm{rad} / \mathrm{s}$ oraz 20 $\mathrm{rad} / \mathrm{s}$ przedstawiono na rys. 24, a o częstotliwości $50 \mathrm{rad} / \mathrm{s}$ oraz $100 \mathrm{rad} / \mathrm{s}$ na rys. $25 \mathrm{i}$ rys. 26. 


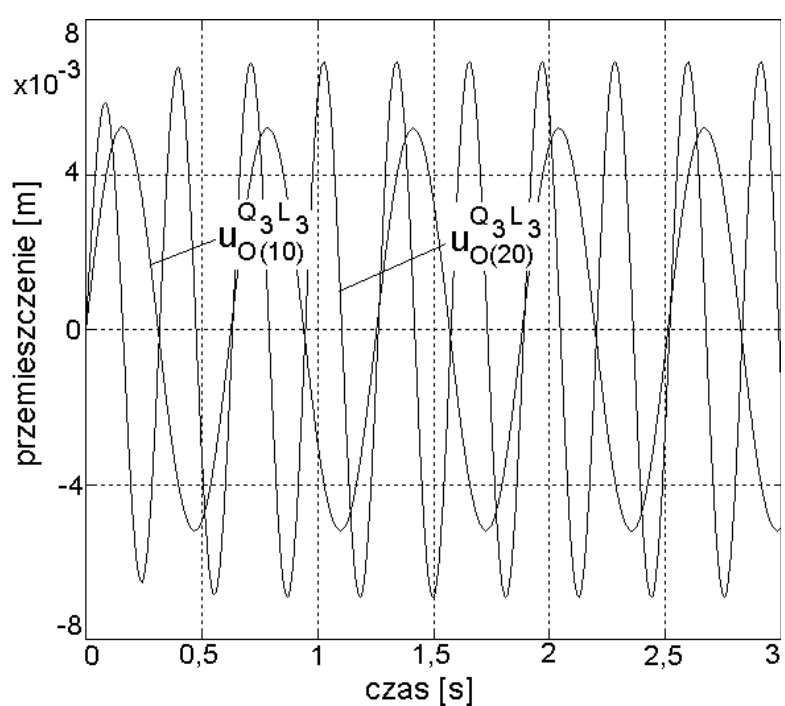

Rys. 24. Przebiegi wejścia $u_{O}(t)$ do układu dla wymuszeń o częstotliwości $10 \mathrm{rad} / \mathrm{s}$ oraz częstotliwości $20 \mathrm{rad} / \mathrm{s}$ dla wybranych wariantów

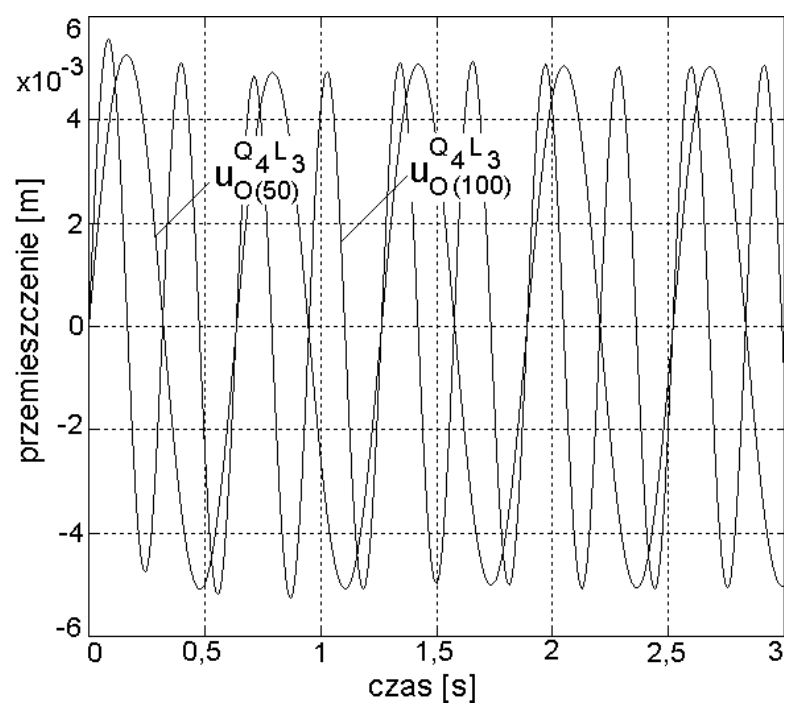

Rys. 25. Przebiegi wejścia $u_{O}(t)$ do układu dla wymuszeń o częstotliwości $50 \mathrm{rad} / \mathrm{s}$ oraz częstotliwości $100 \mathrm{rad} / \mathrm{s}$ dla wybranych wariantów

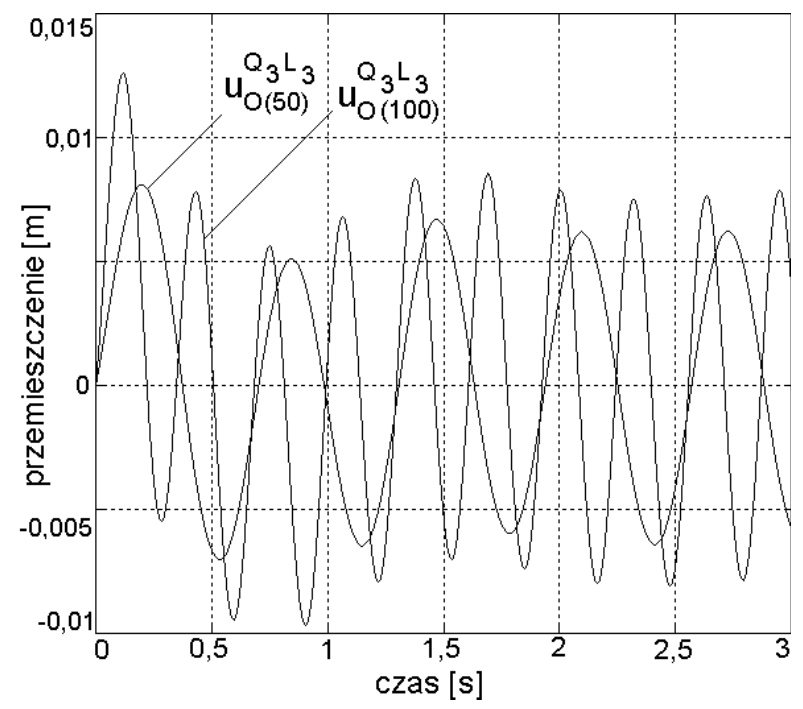

Rys. 26. Przebiegi wejścia $u_{O}(t)$ do układu dla wymuszeń o częstotliwości $50 \mathrm{rad} / \mathrm{s}$ oraz częstotliwości $100 \mathrm{rad} / \mathrm{s}$ dla wybranych wariantów
$\mathrm{Na}$ podstawie przeprowadzonej analizy wyników stwierdzono, że spełnienie warunku niewielkiego wpływu charakterystyk podtorza na charakterystyki własne modelu pojazdu jest możliwe przy przyjęciu do badań macierzy $\mathbf{Q}_{4}$ oraz współczynnika $L_{3}$. Dla tego wariantu wyznaczony współczynnik sztywności podtorza $k_{\mathrm{R}}$ przyjmuje wartość $9,09 \cdot 10^{7}$ $[\mathrm{N} / \mathrm{m}]$.

\section{Podsumowanie}

Celem artykułu było wyznaczenie sztywnościowych i tłumieniowych charakterystyk modelu podtorza przy założeniu, że w układzie występuje sprzężenie zwrotne. Do opisu dynamiki układu zastosowano formalizm transmitancji operatorowej oraz metodę przestrzeni stanu. Do wyznaczania parametrów modelu podtorza, przy przyjęciu podtorza w postaci regulatora proporcjonalnego, zastosowano optymalizację z kwadratowym wskaźnikiem jakości. Badania przeprowadzono w dziedzinie czasu i częstotliwości w zakresie częstotliwości $0 \div 30 \mathrm{~Hz}$. Jako kryterium przy wyznaczaniu parametrów modelu podtorza przyjęto założenie, że wartości własne układu ze sprzężeniem zwrotnym powinny być w przybliżeniu równe wartościom własnym modelu pojazdu.

Wartości współczynnika sztywności i współczynnika tłumienności podtorza uzyskane w wyniku przeprowadzonej analizy numerycznej odpowiadają wartościom prezentowanym w literaturze fachowej. Wykonana analiza świadczy o celowości dalszego rozwijania zaproponowanej metody wyznaczania parametrów modelu podtorza w aspekcie jej wykorzystania w procesie projektowania pojazdów oraz przy prowadzeniu badań eksperymentalnych toru.

Prowadzone są dalsze badania dla przestrzennego modelu pojazdu i toru.

\section{Literatura}

[1] Kaczorek T., Teoria sterowania $i$ systemów, PWN, Warszawa 1993

[2] Knothe K., Wu Y., Gross-Thebing A., Simple semianalytical models for discrete-continuous railway track and their use for time domain solutions, Supplement to Vehicle System Dynamics, Band 24, Swets \& Zeitlinger, 1995

[3] Ogata K., Modern Control Engineering, Prentice-Hall Inc., 1997

[4] Dynamika układu mechanicznego pojazd szynowy-tor, praca zbiorowa, PWN, Warszawa 1991

[5] MATLAB wersja 5 